\title{
Reference Information Model
}

National Cancer Institute

\section{Source}

National Cancer Institute. Reference Information Model. NCI Thesaurus. Code C80496.

An object oriented information model to harmonize the definition of HL7 messages across different application domains. 